\title{
Review
}

\section{Political theology of international order}

\author{
William Bain \\ Oxford University Press, Oxford, 2020, xiv+254 pp., \\ ISBN: 978-0-19-885990-1
}

Contemporary Political Theory (2022) 21, S90-S93. https://doi.org/10.1057/s41296021-00474-0; published online 23 February 2021

The social sciences are full of origin myths. They are the product of rituals through which we try to tame history and thought to the needs of teaching and, at times, of hasty and biased research. Suffice it to mention the myth of the 'founding fathers' of sociology - Comte, Marx, and Weber - or that of Westphalia, according to which political modernity was inaugurated through the magic formula cujus regio, ejus religio. To be sure, simplifications are sometimes necessary for didactic or heuristic reasons. If used in excess, however, they can create major epistemological problems: think, for example, of the constellation of problems, phenomena, and authors obscured by the concept of modernity, or of the transformation of ideal types into historical essences (e.g. 'the Orient', 'bureaucracy', 'sovereignty'). The issue here is that simplifications possess a normalizing power precisely because they are easily understood. Thus we end up dividing history into misleading and artificial dichotomies: sacred and secular, medieval and modern, material and ideational. And among all such mythologies, the one that indissolubly links the secularization process to the birth of the modern interstate system is certainly the most rooted and widespread in the academic imaginary.

In this masterful work, William Bain demolishes many of the myths that still underlie the discipline and history of international relations, showing precisely how 'modern theories of international order are intelligible in historical patterns of thought that take shape in late medieval theology' (p. 4). To this extent, Political Theology of International Order is an important addition to the now classic studies that have called into question the scope and nature of the so-called process of secularization - I am thinking, first of all, of Carl Schmitt's 1922 work, to which Bain makes explicit reference right in his book's title. The fundamental argument that guides the book is that far from being the fruit of a secular and a-theological worldview, modern conceptualizations of order rest on assumptions that are nothing but a worldly application of a theological pattern. More specifically, the categories, analogies, and metaphors through which modern thinkers conceived their ideas of order 'are rooted in a medieval theological dispute about the nature of

(C) 2021 The Author(s), under exclusive licence to Springer Nature Limited part of Springer Nature. 14708914 Contemporary Political Theory Vol. 21, S2, S90-S93 www.palgrave.com/journals 
God and the extent of his power' (p. 224). From this ancient dispute emerged two alternative interpretations, which attempted to combine the regularity of the natural order with God's freedom, that is, the rationality of the world with the will of that God who created it ex nihilo: the theory of immanent order and the theory of imposed order. According to the former, the "natures of mutually related things jointly compose an interconnected whole. This whole imparts a necessary and rationally intelligible pattern of place and purpose, knowledge of which is acquired by investigating both efficient and final causes'. In contrast, the theory of imposed order holds that 'singular things, having no intrinsic connections, enter into relations that are imposed from without, either by legislation or the force exerted by an impersonal mechanism. The result is a contingent rather than necessary patter or order', knowledge of which is possible by empirical observation and the investigation of efficient causes (p. 7, emphasis added).

From this perspective, Bain traces a convincing genealogical reconstruction of the intellectual presuppositions of a range of important modern authors, showing how they elaborated their ideas of order by means of theological analogies and categories, which, in the end, will be veiled by secular discourses. Starting from the analysis of Luther's 'two kingdoms' framework, and passing through a re-reading of Grotius's political and legal thought up until Hobbes's Leviathan, Bain reveals the 'structural continuity' that lies behind their doctrines. This initiatory path culminates in the demonstration that 'the ubiquitous picture of independent states interacting in a condition of freedom, subject to an impersonal mechanism like the balance of power or voluntary rules legitimized by consent, reflects the theory of imposed order and presuppositions inherited from nominalist theology. This way of comprehending the world migrated from theology to politics and law with the help of a recurring analogy between God and worldly affairs' (p. 224).

At this juncture, however, the explanatory power of Bain's narrative raises some methodological and interpretative questions regarding the nature and significance of this continuous change of ideas within an inherited theological framework. In other words, how can one explain the fact that theological ideas constantly 'structure the way in which a pattern of order is comprehended and explained as an object of knowledge' (p. 88)? This question is reminiscent of the debate between Schmitt and Blumenberg on the deep meaning of political theology (Schmitz and Lepper, 2007). This is not the place to discuss in detail the reflections of the two thinkers, who, despite the many differences between them, seem to agree on the fact that the process of secularization involves a reoccupation of the theological apparatus of Christianity (Ifergan, 2010). As Blumenberg (1985, p. 65) has it: 'What mainly occurred in the process that is interpreted as secularization ... should be described not as the transposition of authentically theological contents into secularized alienation from their origin but rather as the reoccupation of answer positions that had become vacant and whose corresponding questions could not be eliminated'. This means that, technically speaking, there is no 'political theology'

(C) 2021 The Author(s), under exclusive licence to Springer Nature Limited part of Springer Nature. 1470- S91

8914 Contemporary Political Theory Vol. 21, S2, S90-S93 
stricto sensu but only a process of functional reoccupation of the conceptual structures inherited from Christianity. It goes without saying that, for Schmitt, this appropriation is 'illicit' because, once deprived of their theological substance, modern categories are as fragile as they are empty. But from the point of view of the history of ideas, this debate is fruitful for understanding the intellectual path illustrated by the book reviewed here.

One can certainly agree with Bain when he argues that Luther did not cut the bridges between the 'sacred' and the 'secular', but, on the contrary, tried to reactivate a 'theologically defensible relation between faith and reason' (p. 95). One can also concur with him that by rethinking the relationship between freedom and necessity, Hobbes drew on the conceptual structures inherited from the theory of imposed order. But the fact is that in answering the questions inherited from tradition (Quis judicabit? Quis interpretabitur?) both scholars have, knowingly (Hobbes) or unknowingly (Luther), changed the genealogical sense and direction of the problem. By removing pontifical mediation, for example, Luther opened an immense conceptual space between man and God. And it is precisely by reoccupying this space that Hobbes was able to reconstruct his idea of political order 'from below'. The Leviathan is, in fact, a transcendental edifice built on immanence, a sum of the wills of individuals who transcend themselves through the social contract. In other words, if Luther abandoned ecclesiastical mediation, Hobbes got rid of mediation in and of itself: there is no longer any need to mediate between man and the 'mortal' God, because the state is nothing but the magnified reflection of the will to power of the 'modern subject'. Although, as Bain rightly argues, Hobbes's thought is 'a logical entailment of a theologically grounded mental universe' (p. 152), the English philosopher reoccupied and turned that universe upside down, thus transforming the individual into the new pivot of the political order (see e.g. Durkheim, 2011).

By showing that theological thinking is the white shadow of political modernity and of its conceptualizations of order, Bain puts the study of international relations back in line with political philosophy and critical theory. However, the doubt remains that this analogical continuity between theological structures and theories of order is exclusively formal and that the reoccupation of the theological substratum, to use Blumenberg's words (1985, p. 60), creates only 'the appearance of a substantial identity lasting through the process of secularization'. Be that as it may, Political Theology of International Order is a work of rare depth and texture, which has the undoubted merit of challenging many of the most widespread political mythologies. In this sense, Bain has fully realized the Weberian ideal of scientific clarity by showing how 'no science is absolutely free from presuppositions' but that, more often than not, these presuppositions are obscure precisely for those who rest on them, blissfully unaware.

S92 (C) 2021 The Author(s), under exclusive licence to Springer Nature Limited part of Springer Nature. 14708914 Contemporary Political Theory Vol. 21, S2, S90-S93 


\section{References}

Blumenberg, H. (1985) The Legitimacy of the modern age. Cambridge, MA: The MIT Press.

Durkheim, É. (2011) Hobbes à l'agrégation. Un cours d'Émile Durkheim suivi par Marcel Mauss. Paris: Editions de l'École des Hautes Études en Sciences Sociales.

Ifergan, P. (2010) Cutting to the chase: Carl Schmitt and Hans Blumenberg on political theology and secularization. New German Critique, 111, 149-171.

Schmitz, A. and Lepper, M. eds. (2007) Hans Blumenberg Carl Schmitt Briefwechsel, 1971-1978, und weitere Materialien. Frankfurt am Main: Suhrkamp.

Publisher's Note Springer Nature remains neutral with regard to jurisdictional claims in published maps and institutional affiliations.

Antonio Cerella

Kingston University, Kingston-upon-Thames KT1 2EE, UK a.cerella@kingston.ac.uk 